Nóra G. Etényi

Eötvös Loránd University, Faculty of Humanities, Early Modern History Department

\title{
Broadsheets with Engravings in a Manuscript Chronicle from Ulm: Visual Representations of the Hungarian Kingdom on German Political Leaflets during the War of Reconquest (1683-1699)
}

\author{
Original scientific paper - Izvorni znanstveni rad \\ Received - Primljen 1. 2. 2019. \\ UDK 7.044:762/766"1683/1699" \\ 930.2Gockel, E.
}

DOI 10.31664/ripu.2019.43.07

\begin{abstract}
The news about the war of expulsion against the Ottoman Empire was presented by a multi-central propaganda. A manuscript chronicle written in Ulm demonstrates the literacy of the broadsheets' readership. The writer, Eberhard Gockel (1636-1703), a physician from Ulm, wrote a diary on the most important occurrences and affairs of the Turkish war from 1678 to 1703 . He attached to his chronicle broadsheets and engravings on the recaptured Hungarian fortresses and the great victories against the Turks. Gockel had good sense for high quality engravings, and he chose the works of publishing houses with excellent reputations, for example Jakob Koppmayer from Augsburg, Johann Jonathan Felsecker and Johann Hoffmann from Nürnberg and

interests of the House of Habsburg, but he mainly focused on the role of the imperial and troops from the region of Swabia. His manuscript illustrated with engravings gives a detailed description of the Hungarian Kingdom's fight against the Turks. Gockel focuses on the news of the anti-Ottoman war of 1683-1688 and he recorded the victories against the Turks even after the French invasion of the Rhineland in 1688. Gockel was critical of the quantity of military news and tried to remain unbiased on political and religious questions. Gockels' chronicle proves that the readers of the broadsheets had all the tools to use the media of that time critically, and that sensibility and curiosity for the news of the world was a significant part of the identity of a citizen in a city like Ulm.
\end{abstract} Michael Wening from München. As a citizen of Ulm, he respected the

Keywords: Eberhard Gockel (1636-1703), broadsheet readers, Great Turkish War (1683-1699), Manuscript Chronicle from Ulm, manuscript illustrated with engravings, illustrated broadsheets

Throughout the early modern period leaflets covering various topics, illustrated with etchings, played a decisive role both in ensuring the rapid flow of information and a more accessible visual communication that was able to reach the broader social strata. Leaflets covering topics of public interest ensured that an outstanding amount of information reached the audience of the Holy Roman Empire in regard to the wars against the Ottomans. This visual form of information broadcasting was able to easily cross national borders and presented the wars as a common European struggle to the broader audience of the $16^{\text {th }}-17^{\text {th }}$ centuries. In relation to the major crises - such as denominational feuds, the Thirty Years' War - the leaflet genre went through changes as well. The intense ecclesiastical and secular propaganda accompanying domestic and international crises, mock-ups of political and military opponents and satirical symbols periodically led to a certain degree of devaluation of the genre. At the end of the $17^{\text {th }}$ century, however, extensive, yet high-quality leaflets appeared covering the events of the Great Turkish War (1683-1699) with reliable textual information and quality etchings. The war against the Ottoman Empire was accompanied by the sophisticated competition for representation among the allies, members of the Holy League and the electors, all the way through from the siege of Vienna in 1683 to the Treaty of Karlóca/ Karlowitz/Sremski Karlovci (Serbia) in 1699. However, the leaflets not only reflected the direct political interests of their source; instead, they conveyed meaningful knowledge of military events, political turning points, the economic value and history of the areas reconquered from the Ottomans, and the changing of the enemy's general perception. The unique $17^{\text {th }}$ century manuscript chronicle proves that educated urban citizens used the visual information provided by leaflets in an intelligent and versatile manner, constituting a realistic picture of the transformation of power in an expanded political space. 
Eberhard Gockel (1636-1703), a doctor from Ulm and as such an educated urban citizen, composed an immensely valuable chronicle between 1678 and 1703, the first part of which presented the city's history from the Middle Ages, while the second part was a contemporary historical summary. It exhibits the significant changes in Gockel's hometown, the narrower region, the Swabian district and the Holy Roman Empire, of which he captured the events of the war against the Ottomans in Hungary with the greatest detail. ${ }^{1}$ Gockel's record, rich in information, is evidence of a sophisticated relationship between the author and visual communication. The doctor used sixty leaflets illustrated with etchings, cityscapes and portraits as insertions in his manuscript.

What could have been Eberhard Gockel's goal with the manuscript for several decades though? Gockel published a great deal, but his works in connection with his rise in status were all related to his chosen profession of medicine. Following his studies in Tübingen and Basel, Gockel started his first practice in Ulm. This was followed by a practice in Geislingen from 1659 and then Giengen from 1675, shortly after which in 1678 he became the physician of the Weiltingen branch of the Ducal family of Württemberg. ${ }^{2}$ In 1685 he became a member of the Academy Leopoldina, which was founded in 1652 in Schweinfurt, and renamed after Emperor Leopold in 1687. ${ }^{3}$ The institution became the German Academy of Natural Sciences some time later. Gockel's name is also recognized in the history of science, as he identified a poisonous disease (colica pictonum) that reappeared around the end of the $17^{\text {th }}$ century and was caused by must fermented in lead vessels. ${ }^{4}$ His successful

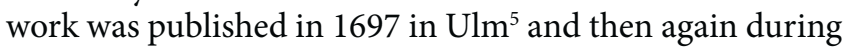
the spring of 1699 in Augsburg, Frankfurt and Leipzig. In 1700, he dedicated his 300-page Latin language digest on his medical activities to Emperor Leopold. ${ }^{6}$ Gockel might have been inspired by the high-quality natural science literacy among the higher classes of Ulm, and its increased interest in medicine. ${ }^{7}$ Eberhard Gockel's father Johann Georg Gockel was the head of the prestigious Collegium Medicum of Ulm between 1679 and 1693, and Eberhard became a member in 1677, while his son, Christoph, became one in $1700 .^{8}$

Gockel did not intend to publish his chronicle in the short term, but rather gathered his Ulm-centered observations at the time of an epochal change for an urban chronicle that was to be published later. Gockel did not conduct an "official" urban chronicle, capturing instead important "outside world" events for his city, focusing mainly on the Great Turkish War. Gockel did not write a diary, although he did record his own role in setting up a camp pharmacy for Ulm's reserve army, ${ }^{9}$ and when he examined the health of soldiers returning from the war.

In the cities of the Holy Roman Empire, besides printed urban stories and manuscript logs, chronicles were also an important part of community representation, conveying the ideal image of the city..$^{10}$ Gockel used ${ }^{11}$ the Ulm urban chronicle, published in $1653,{ }^{12}$ which was based on urban chronicles by Martin Zeiller, a well-known editor. ${ }^{13}$ Gockel also included the Ulm cityscape in his chronicle from Matthäus Merian's Topographia. ${ }^{14}$

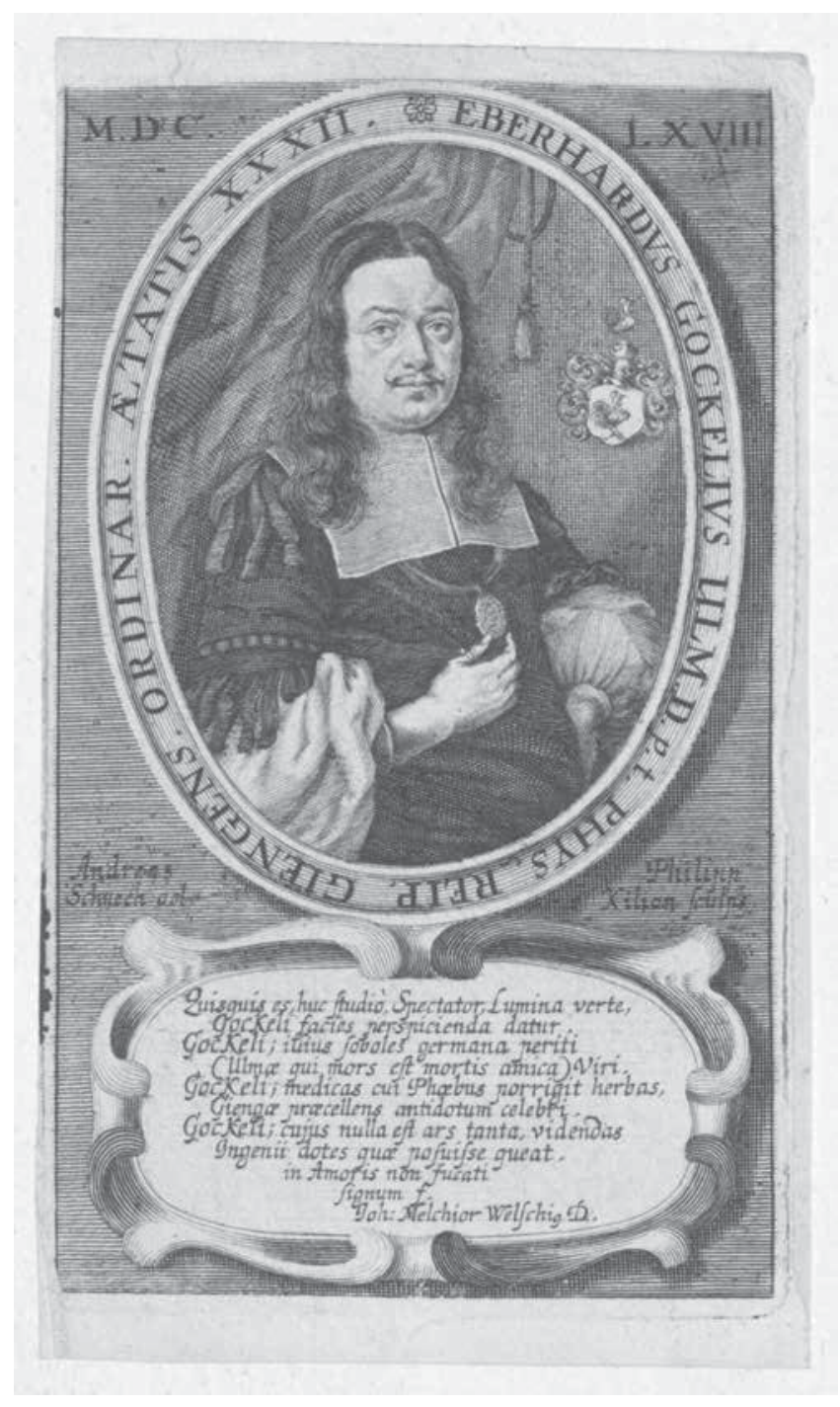

1. Philipp Kilian - Andreas Schuch, Eberhard Gockel, 1668, 7352904 Port_00073270_01 $(1001 \times 1680 \mathrm{~mm})$, Austrian National Library, Portrait Collection

Philipp Kilian - Andreas Schuch, Eberhard Gockel, 1668., 7352904 Port_00073270_01 $(1001 \times 1680 \mathrm{~mm})$, Zbirka portreta Austrijske nacionalne knjižnice

Gockel also regarded the tradition of urban history manuscripts as a base model, and therefore used Marchthaler's Ulm Chronicle as well as a base model. Several generations of Marchthalers had captured their far-reaching trips as textile traders. Veit Marchthaler (1564-1641) spent many years in Hungary. ${ }^{15}$ Using the manuscript of Veit Marchthaler (1564-1641), Martin Zeiller published his best-selling work on the cities of the Hungarian Kingdom in Ulm, which later had six updated editions between 1646 and $1690 .{ }^{16}$ Publishers from Ulm (Kühn, ${ }^{17}$ Wagner) guided the release of many geographic descriptions and travel guides, including numerous Hungarian references.

Eberhard Gockel relied on the conventions of urban chronicles, ${ }^{18}$ but he also modernized this traditional genre with knowledge deriving from contemporary scientific achievements. The doctor recorded the earthquakes of Ulm, ${ }^{19}$ the appearance of comets ${ }^{20}$ and weather phenomena, and he 
also logged the quality of fruit and grain production, and the navigability of the Danube in relation to long, cold winters, dry summers and rainy springs (Fig. 2).

Gockel legitimised his own role as a contemporary historian with an introduction covering the city's medieval history, displaying the golden age of Ulm. However, by the last third of the $17^{\text {th }}$ century, Ulm's wine, luxury and spice trade, as well as its textile industry, did not bring such significant profits as in the $15^{\text {th }}$ century. ${ }^{21}$ However, the Danube, navigable from Ulm, continued to provide a great opportunity to trade with the imperial capital. ${ }^{22}$ The Swabian reserves embarked for their journey in Ulm to reach the theatre of war during the Great Turkish War, and from 1712 onwards, the city served the same purpose for the German settlers leaving for their new homes in the recaptured area. Gockel noticed that Ulm's $17^{\text {th }}$-century political significance was closely associated with an active role in the struggle against the Ottomans, which was systematically recorded by the author between 1683 and 1699. The manuscript is dominated by the events of the war against the Ottomans from 1683 to 1688 , up until the French attack that threatened the city of Ulm directly. However, even beside the records of the rapid and devastating advancement of the French army along the Rhine in 1688-1689, the news of the Hungarian War continued to be represented - albeit with decreasing intensity - up until 1699.

Gockel's information was reliable and provided a realistic picture of the events of the war of reconquest. However, the author did not mention where he obtained his information. The doctor also included etchings and pamphlets in his manuscripts about the great victories over the Ottomans, and about the castles that had been recaptured. The visual material demonstrates that the chronicle writer has consistently gathered all the essential knowledge available. The engravings depicted specific castles and cityscapes, as well as busy pictures of battles in a few select cases. The visual reports brought the military scene closer to the audience, although it was not the military engineering plans, military reporting and war diaries that the chronicle writer found particularly interesting: he was fascinated primarily by the cityscapes. The thirty etchings inserted in the second half of the chronicle - including the extensively informative vedute of Eger, Székesfehérvár, Belgrade, Kanizsa, Gyula, Várad/Grosswardein/Oradea/ (Rumania) and Temesvár/Temeswar/Timişoara (Rumania) - prove that the author made his choices consistently when selecting from the plethora of news available. Gockel systematically screened against direct propaganda and did not incorporate a large number of published equestrian portraits, anti-Turkish mockery, and political allegories interpreting power relations. His chronicle only included two semi-portraits in the section dedicated to topicalities. In 1687 he included a portrait of Joseph I, which emphasized the young age of the Crown Prince, ${ }^{23}$ who was being crowned the King of Hungary at the time (Fig. 3). On the $12^{\text {th }}$ of August 1689, despite being a pious Lutheran, he inscribed an etching of Pope Innocent XI, commenting positively on the role of the deceased in organizing the war against the Ottomans and counterbalancing the aggressive foreign policy of Louis XIV. ${ }^{24}$

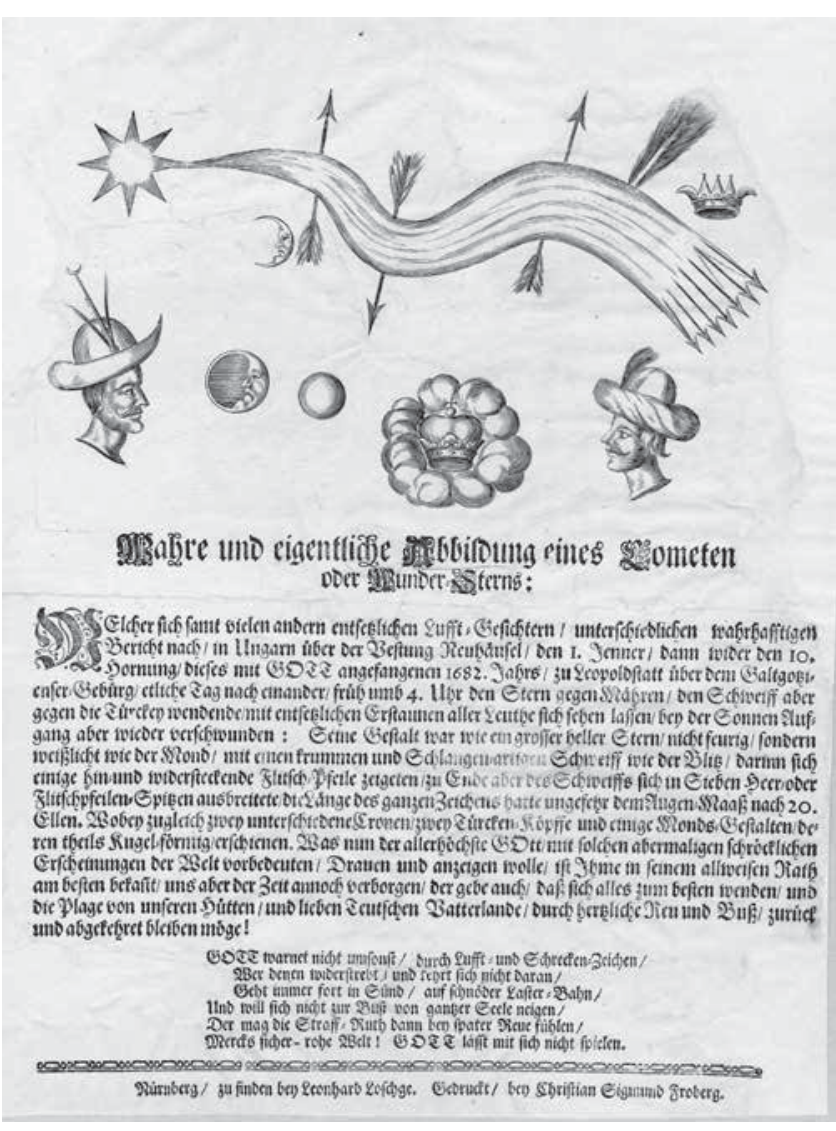

2. "Wahre und eigentliche Abbildung eines Cometen oder WunderSterns" (Comet observed over Nové Zámky on 1 January and again over Leopoldstadt on 10 February 1682 predicting the Ottoman invasion.), "Nürnberg, zu finden bey Leonhard Loschge, gedruckt by Christian Sigmund Forberg", 1682, T $1073(3430 \times 4530 \mathrm{~mm})$, Hungarian National Museum

"Wahre und eigentliche Abbildung eines Cometen oder WunderSterns" (Komet viđen iznad Nové Zámky 1. siječnja i ponovno iznad Leopoldstadta 10. veljače 1682. kao predznak osmanske invazije.), "Nürnberg, zu finden bey Leonhard Loschge, gedruckt by Christian Sigmund Forberg", 1682., T 1073 (3430×4530 mm), Mađarski narodni muzej

For the first part of Gockel's chronicle, he selected representative portraits of dominant members of the Church as well as the secular elite of Ulm, commemorating his contemporaries and their great predecessors with half-portraits and short poetic biographies. Gockel used high quality works by well-known South German craftsmen in his manuscript. In most cases Augsburg artists specialising in portraits were responsible for the portraits, such as the members of the Kilian dynasty: Lucas (1579-1637), Wolfgang (1581-1662), Philipp (1628-1693) and Bartholomäus (1630-1696). Gockel also used several etchings by Leonhard Heckenauer (1627-1704) an Ulm craftsman, who studied at the Merian publishing house in Frankfurt am Main and later practiced his craft mainly in Augsburg. ${ }^{25}$ The works of an Ulm painter, Andreas Schuh (1645-1680), also played an important role in the rapid preparation of the Augsburg etchings. The religious and secular elite of Ulm knew the representational potential of etching portraits very well and took advantage of them accordingly. ${ }^{26}$ Printed portraits of all $17^{\text {th }}$-century preachers 
of the cathedral of Ulm remained intact without exception. Eberhard Gockel's appearance is known to us through ten different half-portrait etchings, with three distinct variations, from his published volumes. ${ }^{27}$ Gockel inserted two of his own portraits in his chronicle: Andreas Schuh and Philipp Kilian's engraving in $1668,{ }^{28}$ and another noticeably later portrait where he is seen wearing a white wig. The latter one was made by Georg Andreas Wolfgang (1631-1716), an Augsburg artisan, in 1700 (Figs. 1, 4). ${ }^{29}$

The visual inclusions of the manuscript chronicle prove that Gockel was primarily attempting to capture the rapid information flow of the Great Turkish War through leaflets. The doctor used both leaflet reports and printed text, rich in historical and geographical information at the same time. Gockel did not copy the text of the leaflets into his manuscript, merely used them to support the credibility of his knowledge with carefully selected prints. For Gockel, the leaflets contained the information in a compact, easily digestible way for contemporaries and even the audiences of later ages.

Gockel collected quality leaflets from acclaimed Augsburg, Nürnberg and München publishers. During the second half of the $17^{\text {th }}$ century, Augsburg and Nürnberg were considered the most productive and best quality leaflet centres in the Holy Roman Empire, ${ }^{30}$ where traditionally a significant number of Hungarian-related leaflets and news about the Great Turkish War appeared. Gockel bought most of his etchings from Jakob Koppmayer (1640-1701). This Augsburg publisher was responsible for the largest number of leaflets on the events of the war of reconquest, consistently following the turning points of the Great Turkish War between 1683 and 1699. ${ }^{31}$ Koppmayer's remaining forty leaflets represent a rather similar taste and value system to Gockel's chronicle. Jakob Koppmayer published reliable and meaningful news leaflets; he did not publish mocking imagery however, and published but a few glorifying equestrian portraits of Emperor Leopold I. The Augsburg master also published large, volatile leaflets in another format, including the etchings folded in separately. He later republished the cityscape as a historical and geographical summary, partly as a business move, and partly as an attempt to collect practical knowledge in a format with longer relevancy. The etching of Vác and Nógrád in Gockel's chronicle matches the depiction of Delineatio Provinciarum Pannoniae et Imperii Turcici by Johann Christoph Wagner (1640-1703?). ${ }^{32}$ Johann Christoph Wagner's work was published by Koppmayer in 1684 and then between 1685 and 1688 in four volumes, which were continuously updated.

Although München was not considered a prominent centre of etching publication in the early modern era, the impressive printed visual propaganda of the Bavarian elector, Maximilian Emanuel II, with its high quality etching works had a great influence at the end of the $17^{\text {th }}$ century. ${ }^{33}$ The vedute of the military engineer Louis Nicolas d'Hallart and court etcher Michael Wening (1645-1718), published between 1683 and 1691 as leaflets and parts of larger summaries, sought to represent the realistic conditions of the natural and built environment as well as the layouts of castles. ${ }^{34}$ Hallart and Wening published a large four-part view of Buda from the directions of the four points of the compass (west, ${ }^{35}$ north, ${ }^{36}$ east, ${ }^{37}$ and south ${ }^{38}$ ) as well as a bird's-eye

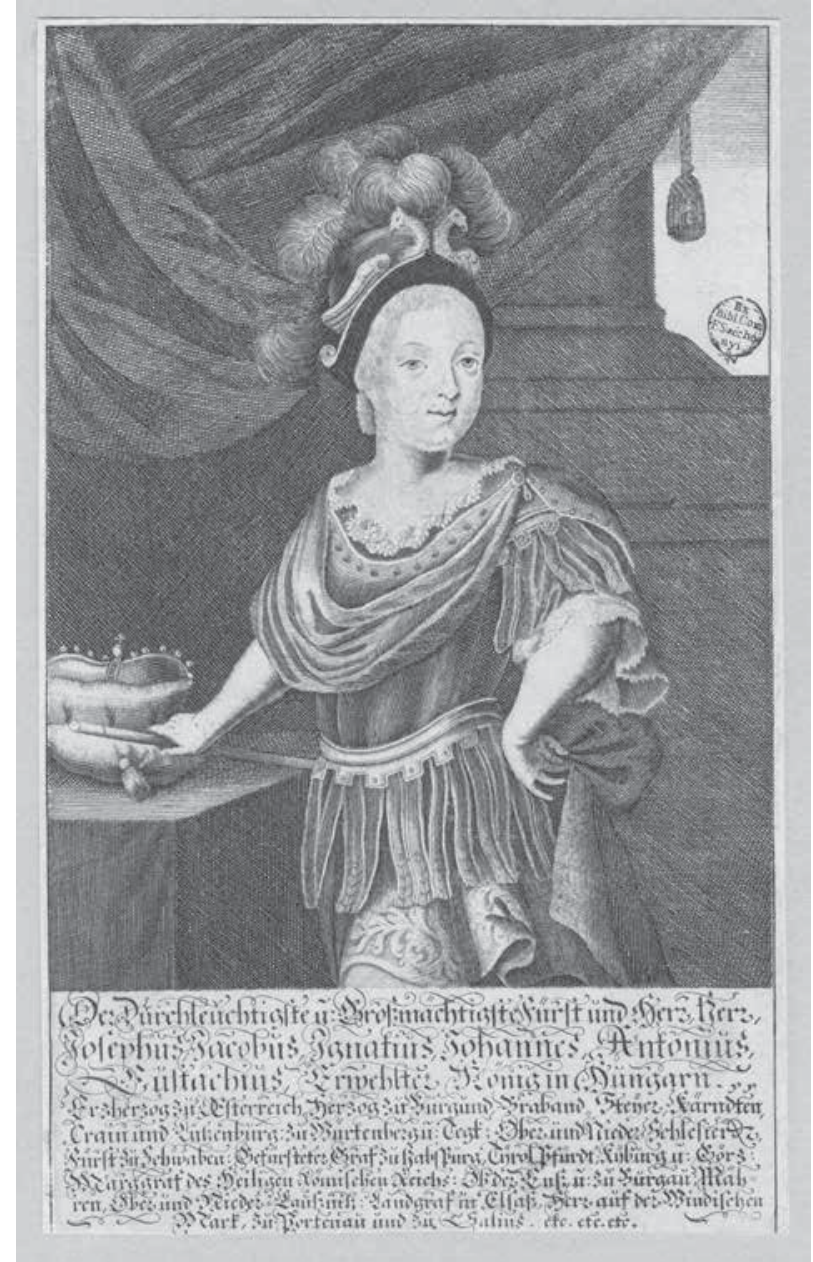

3. Praise of Archduke Joseph as the King of Hungary, 1687, inv. no. $2232(2968 \times 4720 \mathrm{~mm})$, Hungarian National Museum

Slava nadvojvode Josipa kao ugarskog kralja, 1687., inv. no. 2232 $(2968 \times 4720 \mathrm{~mm})$, Mađarski nacionalni muzej

view $^{39}$ as early as 1684, following the unsuccessful siege of Buda. These were also included in a twenty-two piece series depicting the movements of the Bavarian elector's armies in $1686 .{ }^{40}$ Louis Nicolas d'Hallart, the chief army advisor of Emperor Maximilian Emanuel II, was personally present at the siege of Buda in 1684 and in 1686 as well. ${ }^{41}$ Buda's 1686 siege was represented in an extremely large number of leaflets and vedute. ${ }^{42}$ Gockel himself included two depictions of Buda's recapture of 1686 . He purchased a two-part veduta published by the etcher Wening, and drawn by the military engineer Hallart (Fig. 5). These depicted the castle from the direction of both Pest and Székesfehérvár. The large, double depiction included many of the main buildings and defence systems of Buda Castle and provided meaningful information that helped the "civilian" viewers understand the main directions of attack, and the locations of the canons of the imperial armies. ${ }^{43}$ Gockel also included Koppmayer's leaflet from Augsburg, which summarises the history and significance of the castle. ${ }^{44}$

Gockel also purchased works from famous Nuremberg publishers. In the 1680s, ten publishers in Nuremberg also dealt 


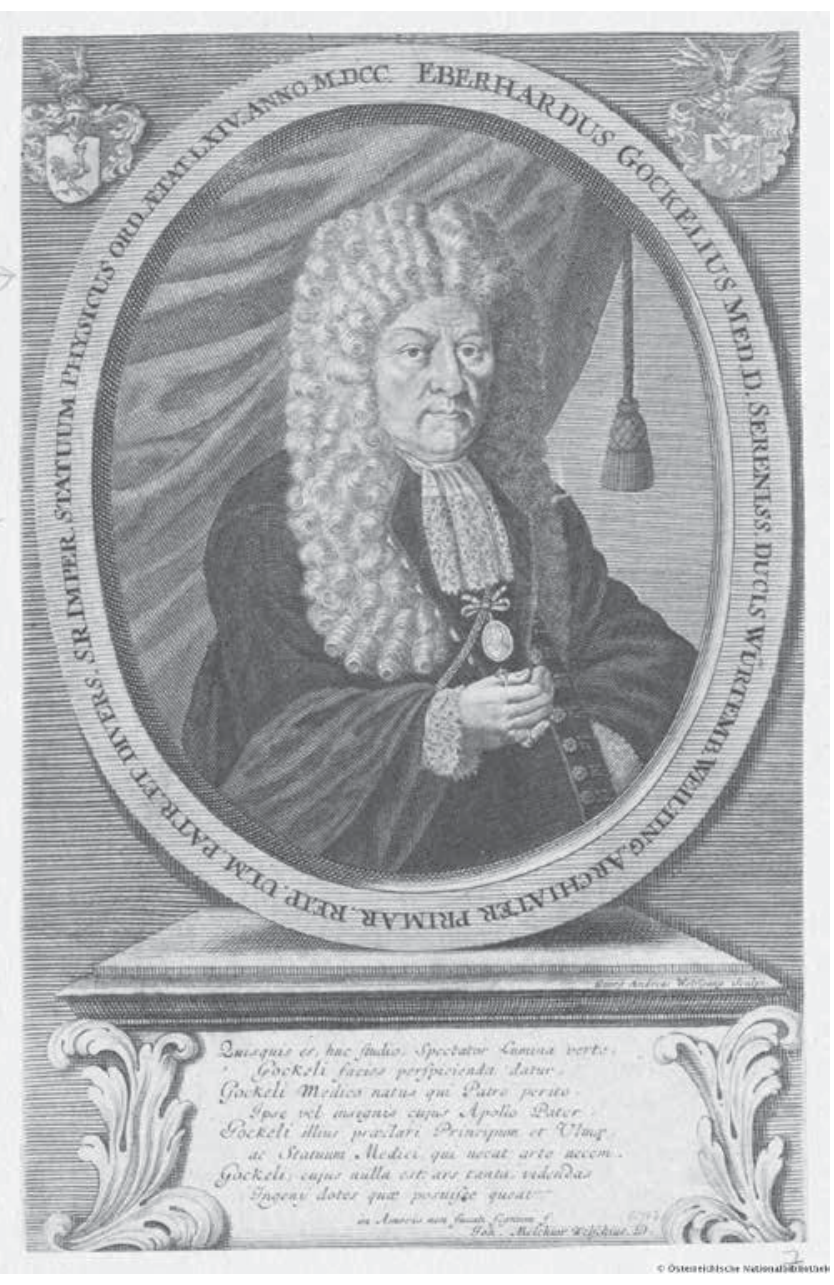

4. Georg Andreas Wolfgang, Eberhard Gockel, 1700, 7352940 Port_00073273_01 $(1113 \times 1680 \mathrm{~mm})$, Austrian National Library, Portrait Collection

Georg Andreas Wolfgang, Eberhard Gockel, 1700., 7352940_ Port_00073273_01 (1113 $\times 1680 \mathrm{~mm})$, Austrijska nacionalna knjižnica, Zbirka portreta

with leaflet publishing, specialising in different fields, but effectively communicating the news of the Great Turkish War in Hungary. The biggest publishing house in Nürnberg - other than the Endters, who did not publish leaflets - was that of the Felssecker family, which also published a weekly newspaper from 1673 onwards. Nine leaflets from Johann Jonathan Felssecker are known to have been published between 1683 and 1699, all including reliable information and etchings with high quality. In 1686, Gockel purchased a leaflet published by the Felssecker, informing about the capture of Pécs and Szeged at the same time (Fig. 6). ${ }^{45}$ The Viennese chronicle was not included in the Ulm Chronicle, but this Nürnberg publication with two etchings shares multiple similarities with Johann Martin Lerch's Vienna print. The Felseckers' carefully established connections in Vienna are clearly represented by the fact that they had played a significant role in Habsburg dynastical representation since the 1670s. In 1682, Gockel included Leonhard Loschge's leaflet informing readers about the approaching war against the Ottomans. The Nürnberg publisher and merchant, Loschge, was active between 1675 and 1700 in the given field. ${ }^{46}$ In 1683, Loschge published fourteen flyers about the Great Turkish War. In regard to the battle of Nagyharsány, Gockel chose to include David Funk's leaflet in the chronicle. ${ }^{47}$ Funk - in cooperation with his father-in-law, the rather talented etcher Johann von Sandrart - published dozens of laudatory equestrian portraits, as well as that of Grand Vizier Kara Mustafa and Sultan Mehmed IV, and even a (fictitious) image depicting captured Turkish noblewomen, and only three leaflets survived in publications about the second stage of the war of reconquest:

Johann Hoffmann gained fame with his informative leaflets. He was active in Nürnberg from 1655 onwards, and 78 of his publications have survived, mostly from the time of the 1663-1664 war. ${ }^{48}$ Gockel's chronicle included one leaflet by Johann Hoffmann, which reported on the destruction of Speyer by the French armies in 1689. Gockel prioritised the inclusion of imagery about the Ottoman theatre of war, but included a few etchings about the military developments along the Rhine and the maritime struggles of the League of Augsburg. In the Holy Roman Empire, the news of northern interests - primarily Dutch and English - were mainly presented to greater audiences by Heinrich Heuss and Thomas Wiering (1640-1703), Hamburg publishers who also printed many Hungarian-related leaflets during the $1680 \mathrm{~s},{ }^{49}$ although they were not included in Gockel's chronicle.

Meanwhile the publisher Wiering in Hamburg and Matthäus Wagner (1648-1694) $)^{50}$ in Ulm collaborated effectively in publishing Eberhard Happel's (1647-1690) novel taking place during the Great Turkish War in Hungary. ${ }^{51}$

Gockel followed the Turkish wars thoroughly, mostly focusing on the Hungarian theatre - occasionally including maritime events, and even more rarely Polish and Russian developments - but an educated urban citizen who was open to this world also found it difficult to transcend the diverse conflicts of power in Europe. Gockel, turning away from the noise of the various theatres of wars, continued his chronicle with decreasing intensity in the 1690s, and added far fewer etchings. Gockel picked up a few leaflets from an unknown publisher about the new English warship ${ }^{52}$ that inflicted heavy damages in the ports of Normandy, as well as about William III and Maximilian Emanuel II's bloodbath ${ }^{53}$ against the Luxembourg Marshal fought on the $19^{\text {th }} / 29^{\text {th }}$ July 1693. After 1688-1690, the large publishing houses published fewer leaflets, as they had changed their strategy to publishing weekly newspapers and other historical-geographic works. Gockel also used a trade fair publication to illustrate his chronicle. The dual etching of Székesfehérvár and Szigetvár was published during the autumn of 1688 in Frankfurt am Main as part of the Relationis Historica Semestralis. ${ }^{54}$ However, the versatile foreign policy analysis of the fair summaries published twice a year was not included in Gockel's manuscript.

He used the intersections consciously to represent the city of Ulm. Gockel did not include etchings of the Ottoman siege of Vienna in 1683, although he did monitor the events closely. On the other hand, he did include three different pictures of the capture of Érsekújvár/Neuhäusel/Nové Zámky (Slovakia) in 1685. Gockel understood the strategic significance of the former Captain General centre's recapture. However, the doctor was not interested in the military event preparing for 


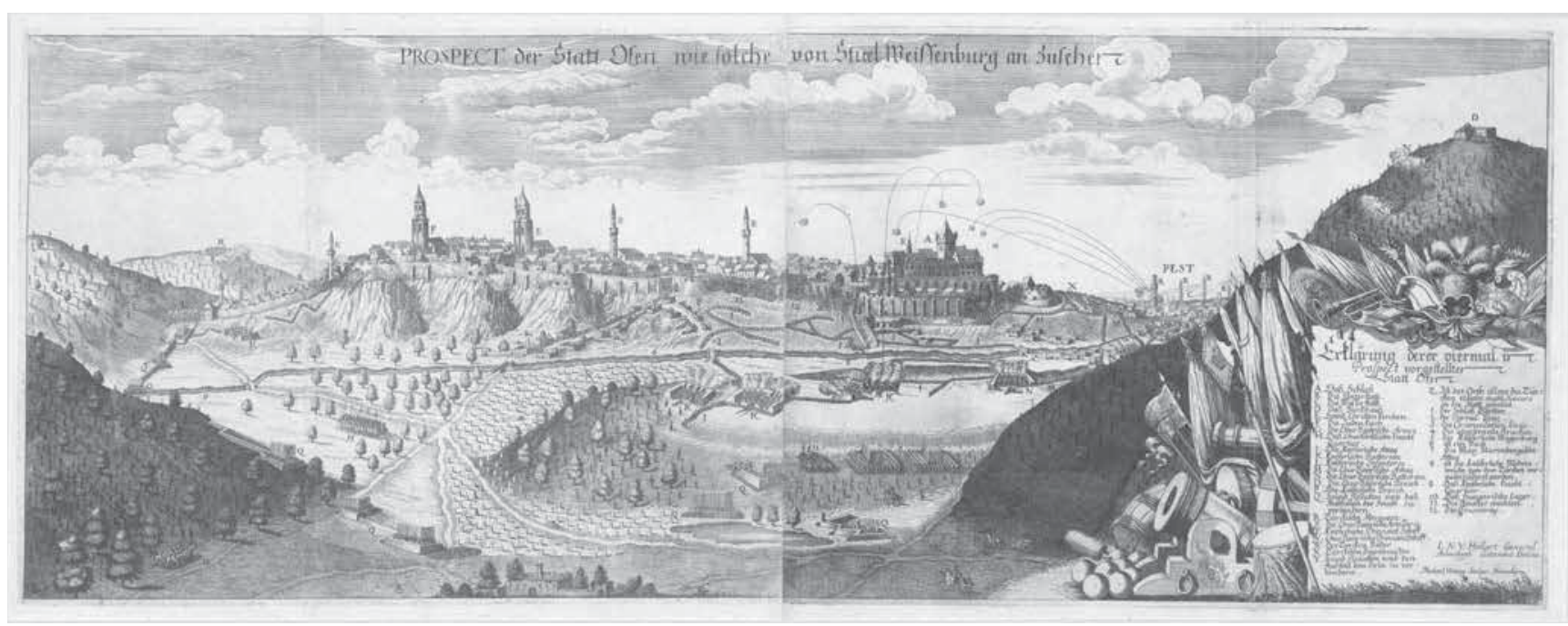

5. Louis Nicolaus d'Hallart - Michael Wening, Siege of Buda (Ofen) by Christian forces, "Prospect der Statt Ofen wie solche von Stuhlweissenburg zusehen", Apponyi Metszet 560

Louis Nicolaus d'Hallart - Michael Wening, Opsada Budima od kršćanskih snaga, "Prospect der Statt Ofen wie solche von Stuhlweissenburg zusehen", Zbirka Apponyi 560

Buda's successful recapture about which Leopold Voigt in Vienna and August Hanckwitz at Regensburg published proper military logs..$^{5}$ The printed logs - in line with Gockel's concept - described the struggle of the 1600 Swabian troops at the last big attack on the $19^{\text {th }}$ of August, highlighting the 300 head strong unit in the right-wing column, which even managed to capture the Ottoman Guard's green flag. ${ }^{56}$ Gockel carefully captured the significant role played by Swabian troops with three etchings. ${ }^{57}$ The "bottom view" depiction of the siege summoned the viewpoint of the Swabian army assaulting the Forgách bastion for the distant chronicler, highlighting the approaching trench, the camp's general atmosphere, and the incendiary bombing of the inner city. ${ }^{58}$ Gockel had acquired a printed layout of Neuhäusel/Nové Zámky (Slovakia) together with fifty labels explaining the locations of the besieging army, highlighting the Swabian reserves at the last big assault.. ${ }^{59}$ The representation of the Swabian district on the third etching is even clearer, two-thirds of which is covered with the military flag of the Ottoman Guard, which was - as a note clarifies captured by the Swabian troops led by Count Charles Gustav of Baden-Durlach. ${ }^{60}$ The bottom part of the picture displayed the same informative layout of Érskújvár without any further explanation included. Gockel inserted this etching into his chronicle at exactly the same section where he described the arrival of Count Charles Gustav of Baden-Durlach in Ulm on the $18^{\text {th }} / 28^{\text {th }}$ November 1685 as the general of the Swabian troops, presenting the Ottoman flag of green silk with Arabic text on it decorated with gold. ${ }^{61}$ The etching was created by the famous painter Johann Ulrich Krauss from Augsburg, who based it on a drawing by Sixtus Kummer from Ulm (Fig. 7). Jacob Koppmayer published a print a few pages long about the Ottoman military insignia, captured at Nové Zámky, in which Matthias Friedrich Beck (1649-1701), a preacher from Augsburg and famous orientalist, interpreted the meaning of the golden inscriptions on the silk flag. ${ }^{62}$ Beck was a member of the Lutheran circle of Gottfried Wilhelm Leibniz (1646-1716) who sought to translate the Quran into German. ${ }^{63}$ Gockel, as a chronicler of the Great Turkish War, systematically captured the unique plunder, the horsetail flags, ${ }^{64}$ yet did not write with noticeable bias about the "archenemy". His attitude was more that of open-mindedness, a scientific interest in the image of the great adversary, as he saw the extensive blood sacrifice of the war in a realistic light.

Gockel presented the military and political role of the Swabian district together, as well as the importance of Ulm for the efficient operation of the territory. In the threatening reality of the anti-Turkish and anti-French wars, imperial districts again became an important factor in the deployment of the military ${ }^{65}$ In addition to the imposing city hall, Ulm was also able to provide a theatre building for the district councils, and the shore of the Danube served as a gathering place for reserve troops. A separate etching was created depicting the departure of the reserves from Ulm as well. ${ }^{66}$

Gockel sensed that the setting up of the Swabian reserves served as an opportunity for the Principality of Württemberg, Count Charles Gustav of Baden-Durlach and Maximilian Emanuel II, the Bavarian elector, to increase their political influence in the region. The Principality of Württemberg, which was loyal to the emperor and a fierce protector of Lutheran interests even beyond the borders of the Holy Roman Empire, also had significant political importance in the Swabian district. Friedrich Charles (1652-1698), Prince of Württemberg, who was ruling in the name of his nephew Louis Eberhard (1676-1733) from 1677 to 1693, was commander of the Lutheran Swabian troops from 1691 onwards. ${ }^{67}$ Gockel also respected Habsburg dynastic interests. In January 1690, the crowning of Joseph I as King of the Romans in Augsburg gave an opportunity to capture the role of Emperor Leopold with two high-quality allegories in the defence of the Holy Roman Empire struggling in the grip of a war on two fronts. Gockel briefly wrote about the 


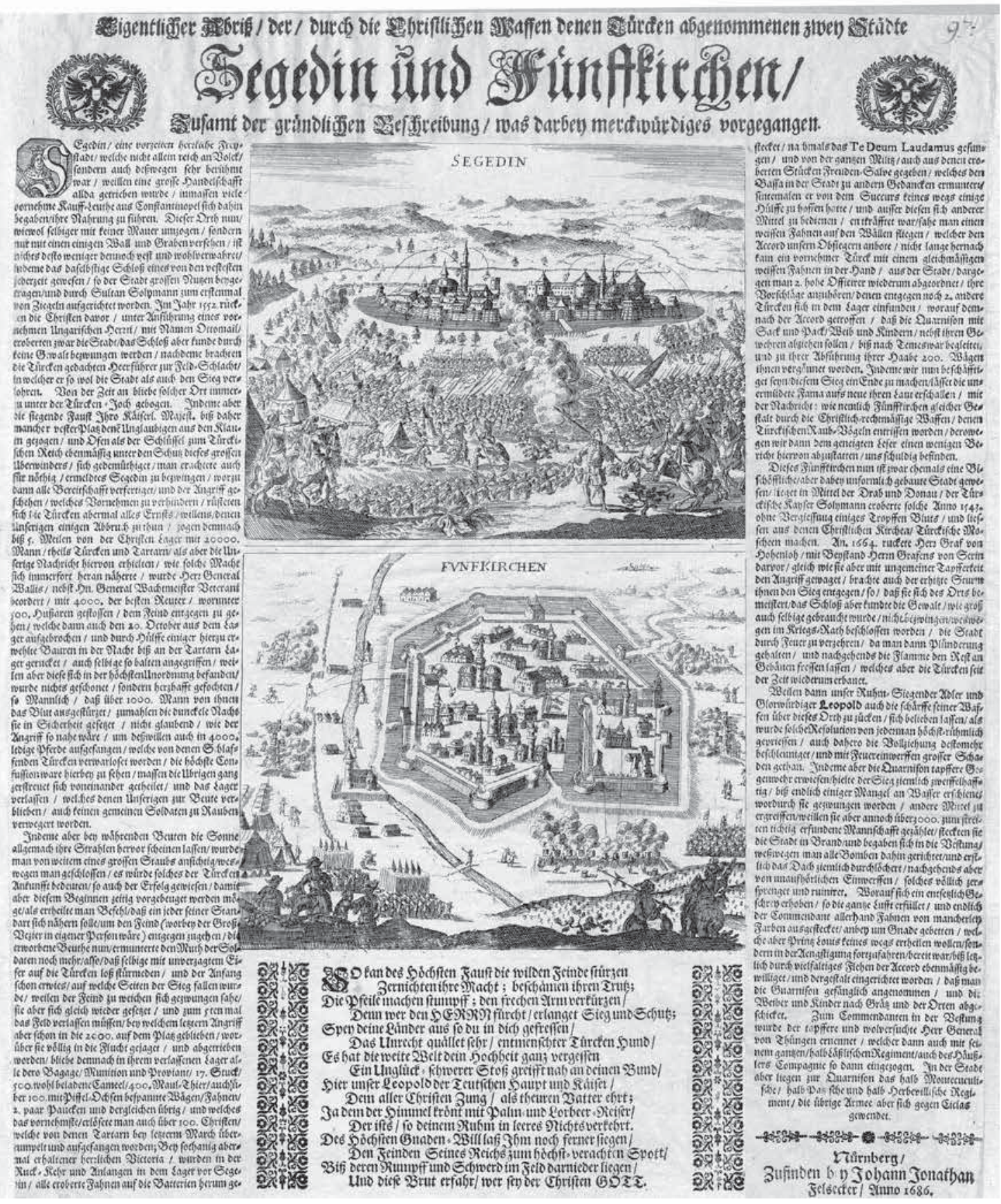

6. The capture of Segedin (Szeged) and Fünfkirchen (Pécs) by Christian forces, 21 October 1686, "Eigentlicher Abriss, der durch die Christliche Waffen denen Türcken abgenommenen zwey Städte Segedin und Fünfkirchen... Nürnberg zu finden bey Johann Jonathan Felsecker Anno 1686", 1686. 10. 21. Szeged, Pécs T 782b (4016×4758 mm), Magyar Nemzeti Múzeum

Zauzeće Segedina i Pečuha od kršćanskih snaga, 21. listopada 1686., 1686. 10. 21. Szeged, Pécs T 782b (4016×4758 mm), Mađarski narodni muzej

celebrations ${ }^{68}$ in Augsburg and Ulm, but placed the two finely crafted, larger allegorical works of 1690 in a prime location at the beginning of the chronicle. On one of them, Emperor Leopold is seen in armour, crowned with a laurel wreath and with his third wife, Eleonore Magdalene von Pfalz-Neuburg, seated on a baldachin throne, next to a female figure offering the olive branch of peace. On the other image, meanwhile, the young King of the Romans, Joseph I, is greeted by the female figures of the reconquered lands: the kneeling Hungary, Serbia, Dalmatia and Slavonia as well as Walachia,
Bulgaria and Transylvania pleading next to a turbaned figure with the inscription "Constantinople". The depiction of Transylvanian vassalage is also noteworthy because in the chronicle there was no meaningful information about the Transylvanian Principality, not even at the recapture of Várad/Grosswardein/Oradea (Rumania) in 1692. A versatile depiction of Hungary can be observed in the chronicle from the vedute of the recaptured towns. Gockel made no reference to the domestic political relations of Hungary, neither the Parliament of 1687, nor the Hungarian nobility on the 


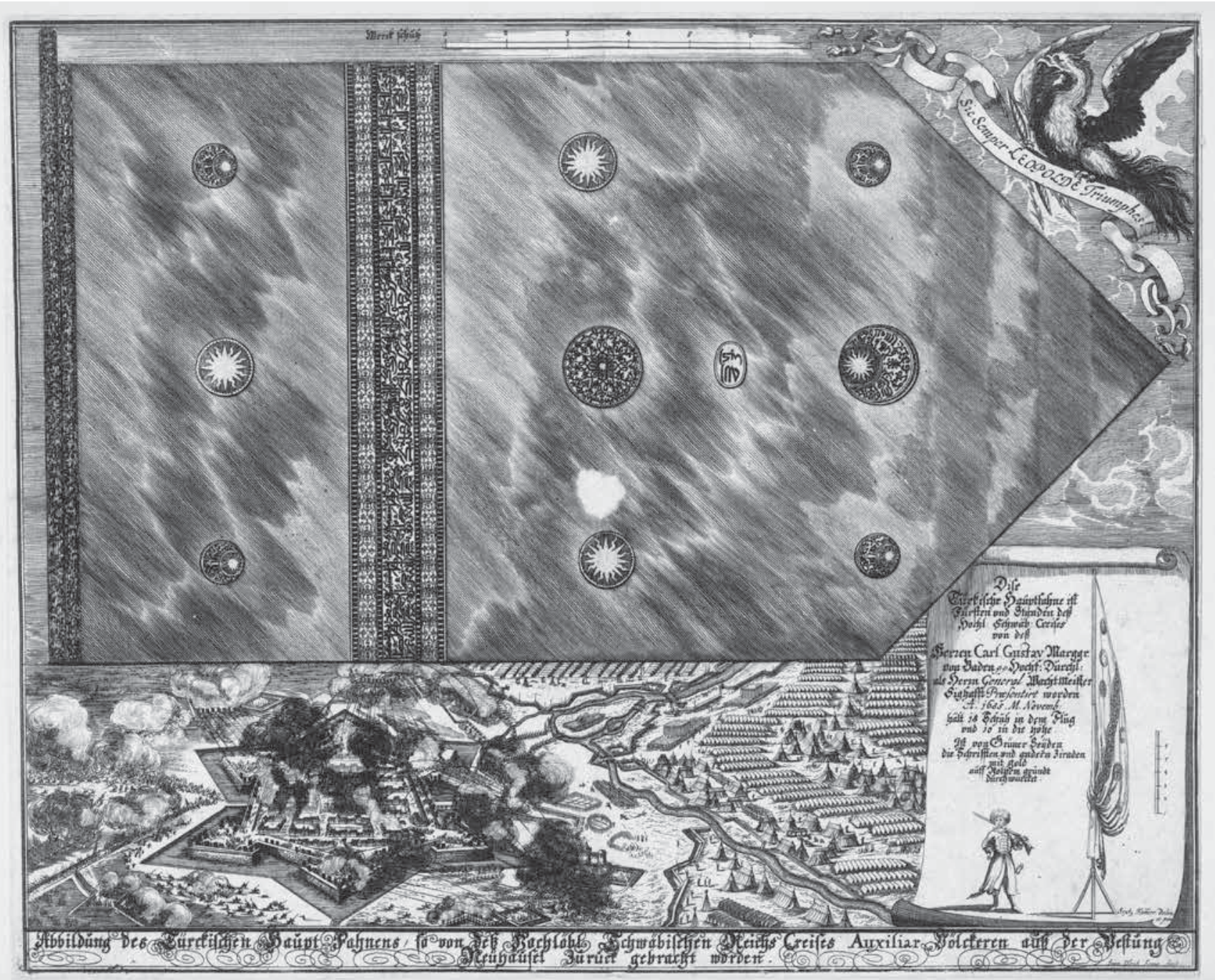

7. J. Ulrich Krauss - Ch. Kümmer, Ottoman Military Flag with view of Neuhäusel (Nové Zámky), 1685, "Abbildung des Türckischen HauptFahnens..., Apponyi Collection (Apponyi Metszet), 398

J. Ulrich Krauss - Ch. Kümmer, Osmanska vojna zastava s vedutom utvrde Nové Zámky, 1685., "Abbildung des Türckischen Haupt-Fahnens...”, Zbirka Apponyi 398

side of Imre Thököly or the emperor. The Wagner publishing house in Ulm had published many forms of Thököly's policy, such as Daniel Speer's novel taking place in Upper Hungary including a biography of Imre Thököly, titled $D a$ cian or Hungarian Simplicissimus. ${ }^{69}$ However, Gockel's work was far from Matthäus Wagner's popular, pre-interpreted publications. However, Gockel did not refer to the political and denominational conflicts in his manuscript. The political forum of the Regensburg Imperial Assembly was not included in his chronicle either.

Leaflet compilations ${ }^{70}$ created by the urban citizenry are known from larger printing centres from the early modern age, as well as such urban chronicles where the author included prints. ${ }^{71}$ Georg Kölderer (1550?-1607) from Augsburg also included several newspapers and leaflets in the 2400-page manuscript ${ }^{72}$ he compiled as the scribe of Weiss Trading House between 1576 and $1607 .{ }^{73}$ At the end of the $17^{\text {th }}$ century, however, manuscript summaries that included etchings and leaflets became rare. Gockel used the etchings as tools for informa- tion compression. The visual material served as evidence and reference for the claims in his manuscript. Gockel purchased from renowned publishers, but did not consider artistic quality as his primary concern; instead, the credibility of the visual information served this purpose. He selected etchings carefully; no pictures of mockery, merely entertaining genre paintings or overcrowded political allegories were included in his collection. Gockel used the opportunities inherent in contemporary information capabilities, and collected and described locally important phenomena in the midst of the major transformations in extending space.

The use of etchings by Gockel shows many similarities with that of his renowned contemporary Johann Weichard Valvasor (1641-1693), a true polyhistor. ${ }^{74}$ Although the Carniolan aristocrat Valvasor, who collected 7921 graphics had much greater potential than the Ulm doctor did, yet Gockel selected actual military and political leaflets with a similar view, from 1683 to 1687, also purchasing primarily from Jacob Koppmayer, Johann Jonathan Felsecker and Johann Hoffman. 
Eberhard Gockel's rich and focused chronicle written over two decades proves that educated citizens of imperial cities at the end of the $17^{\text {th }}$ century were well informed through printed news, consciously using visual information and etching based representation for the eternalisation of their worldview, social status and the values of their urban environment.

\section{Notes}

1

Ulmischer Chronik Beschreibung der Statt Ulm Anfang, Auffnahm, Policey, Grabräuchen und was sich sonsten darin denckwürdiges begeben. Auss weyland Herrn Veit Marchtalers sel. und anderer geschriebenen Chronicken mit grosser Mühe zusammengetragen von Eberhard Gockel 1678; Haus der Stadtgeschichte. Stadtarchiv Ulm G 1 1703/1 (hereafter: G 1 1703/1).

I would like to thank Dr Gudrun Litz for her help in the Stadtarchiv Ulm and Thematic Excellence Program Community building: family and nation, tradition and innovation.

2

ALBRECHT WEYERMANN, Nachrichten von Gelehrten, Künstlern und andern merckwürdigen Personen aus Ulm, Ulm, 1798, I, 264-266; AUGUST HIRSCH, Gockel, Eberhard, in: Allgeimeine Deutsche Biographie, 9 (1879), $305<$ www.deutsche-biographie. de/pnd122370643>; GERD ZILLHARDT, Der Dreissigjährige Krieg in zeitgenössischer Darstellung Hans Heberles "Zeytregister" 1618-1672. Aufzeichnungen aus dem Ulmer territorium, Ulm, $1975,68-72$.

3

See: <www.leopoldina.org/mitgliederverzeichnis/mitglieder/ member/Member/show/eberhard-goeckel/> (20 October 2019).

4

JOSEF EISINGER, Lead and Wine Eberhard Gockel and the Colica pictonum, in: Medical History, 26 (1982), 279-302; Encyclopedia of Epidemiology, 1, (ed.) Sarah Boslaugh, Los Angeles, 2008, 320; GUENTHER B. RISSE, New Medical Challenges during the Scottish Enlightenment, Amsterdam and New York, 2005, 208.

EBERHARD GOCKEL, Eine curiose Beschreibung dess An 1694. 95. und 96. durch das Silberglett versüssten sauren Wiens und der davon entstandenen (...), Ulm, 1697.

6

EBERHARD GOCKEL, Gallicinium Medico-Practicum. Sive Consiliorum, Observationum et Curationum Medicinalium Novarum Centuriae Duae, Cum Dimidia (...), Ulm, 1700.

7

THEO PRONK, Ulm, in: Handbuch kulturellen Zentren der Frühen Neuzeit: Städte und Residenzen, (eds.) Wolfgang Adam, Siegrid Westphal, Berlin, Boston, 2013, 2005-2054.

8 ALEXA GROB, Das Collegium Medicum zum Ulm, PhD diss., University of Ulm, 2007, 15, 35-40.

9

G 1 1703/1, f. 440v, 1685. 11 May.

10

GÜNTHER LOTTES, Stadtchronistik und städtische Identität. Zur Erinnerungskultur der frühneuzeitlichen Stadt, in: Mitteilungen des Vereins für Geschichte der Stadt Nürnberg, 87 (2000), 47-58.
11

G 1 1703/1, f. 398 .

12

MARTIN ZEILLER, Chronicum Parvum Sueviae, Oder Kleines Schwäbisches Zeitbuch, Ulm, Kühn, 1653.

13 WALTER BRUNNER, Martin Zeiller (1589-1661) Ein Gelehrtenleben, Graz, 1989.

14 Engraving of Georg Rieder d. J. (1570); HANS EUGEN SPECKER, Ulm, in: Das Bild der Stadt in der Neuzeit 1400-1800, (eds.) Wolfgang Behringer, Bernd Roeck, München, 1999, 392-396.

15

ŠTEFAN KAZIMÍR, Die Ulmer Kaufleute in Ungarn im 16. und 17. Jahrhundert, Ulm und Oberschwaben, in: Zeitschrift für Geschichte und Kunst. Mitteilungen des Vereins für Kunst und Altertum in Ulm und Oberschwaben, 44 (1982), 308-317.

16

MARTIN ZEILLER, Newe Beschreibung dess Königreichs Ungarn, Ulm, 1646; NÉMETH S. KATALIN, Eine wiederentdeckte Reisebeschreibung. Veit Marchthaler, Ugarische Sachen, 1588, in: Deutschland und Ungarn in ihren Bildung-und wissenschaffts Beziechungen während der Renaissance, (eds.) Wilhelm Kühlmann, Anton Schnidling, Stuttgart, 2004, 207-208.

17

ELMER SCHMITT - BERNHARD APPENZELLER, Balthasar Kühn. Buchdruckerei und Verlag Kühn, Ulm 1637-1736, Weissenhorn, 1992.

18

VOLKER PFEIFFER, Die Geschichtsschreibung der Reichsstadt Ulm von der Reformation bis zum Untergang des Alten Reiches, (Forschungen zur Geschichte der Stadt Ulm, 17), Ulm, 1981.

19

G 1 1703/1, f. 479v. 1689 Mittwoch den 11 Xbris Morgens eine halbe vierdtel Stund nach 2 Uhr ist ein Erdbeben so zetren stöss gethan allhie zu Ulm [...] gespä/öhret worden.

20

G 1 1703/1, f. 434. 1682. dec 30. Abend um 7 Uhr ist eine feurige Kugel (...) über die Statt Ulm geflogen.

21

HANS EUGEN SPECKER, Ulm. Stadtgeschichte, Ulm, 1977, 168-173; OLIVER FIEG, Das Ulmer Patriziat zwischen Zunftbürgertum und Landadel, in: Adel im Wandel. Oberschwaben von der Frühen Neuzeit bis zur Gegenwart, (eds.) Mark Hengerer, Elmar L. Kuhn, Ostfildern, 2006, 631-642.

22

HANS-HENRICH WANGEROW, Handel und Wandel auf der Donau von Ulm bis Wien in den Jahren 1583 bis 1651, in: Ulm und Oberschwaben, 57 (2011), 115-168. 
23

G 1 1703/1, f. 458, 1687 den 9 Decemb wurde Josephus Kaysers Leopoldi I Sohn zu Pressburg zum Hungarische König gekrönt; f. $457 \mathrm{v}$ “(...) Josephus Jacobus Ignatius Johannes (...) erwehlte König in Hungarn”; NÓRA G. ETÉNYI, Die Öffentlichkeitspolitik des kaiserlichen Hofes bei der Krönung Josephs I. zum König von Ungarn, in: Das Königreich Ungarn und Königreich Böhmen und der Wiener Hof im 16.-17. Jahrhundert, (eds.) István Fazekas, Anna Fundarkova, Bratislava - Wien, 2013, 175-214; ÉVA GYULAI, Gyermekkirály a Magyar Királyság trónján - I. József koronázásának ikonográfiai reprezentációja [A child king on the throne of Hungary: Iconographic representation of King Joseph I's coronation], in: Történelem és Muzeológia, 2/2 (2015), 18-46, 28.

24

G 1 1703/1, f. 477. 1689.08.3/13.

25

ALBRECHT WEYERMANN (note 2), 164-165.

26

BERNHARDT APPENZELLER, Die Münsterprediger bis zum Übergang Ulms an Württemberg, 1810. Kurzbiographien und vollständiges Verzeichnis ihrer Scrifften, Ulm, 1990.

27

Available at Digitaler Portraitindex - <www.portraitindex.de/ dokumente/pnd/117360201> (20 October 2019).

28

<www.portraitindex.de/documents/obj/33202973>; Wolfenbüttel, Herzog August Bibliothek (hereafter: WHAB) inv. no. A-7866 (20 October 2019).

29

<www.portraitindex.de/dokumente/obj/34007796>; WHAB inv. no. A-7867 (20 October 2019).

30

JOHN ROGER PAAS, Augsburg, die Bilderfabrik Europas. Essays zur Augsburger Druckgraphik der Frühen Neuzeit, Augsburg, 2001; MICHAEL SCHILLING, Die Augsburger Einblattdruck, in: Augsburger Buchdruck und Verlagswesen. Von den Anfängen bis zur Gegenwart, (eds.) Helmut Gier, Johann Janota, Wiesbaden, 1997, 381-404; SILVIA SERENA TSCHOPP, Augsburg, in: Handbuch kultureller Zentren der Frühen Neuzeit. Städte und Residenzen im alten deutschen Sprachraum, (eds.) Wolfgang Adam, Siegrid Westphal, Berlin, 2013, 1-50.

31

JOHN ROGER PAAS, Die Flugblattproduktion des Augburger Druckers und Verlegers Jacob Koppmayer 1640-1701, in: Gestochen in Augburg: Forschungen und Beiträge zur Geschichte der Augburger Druckgrafik. Hommage à Wolfgang Seitz zum 90. Geburtstag 2011, (eds.) John Roger Paas, Josef H. Biller, Maria Luise Hopp-Gantner, Augsburg, 2013, 79-100.

32

BÉLA SZALAI, Magyar várak, városok, falvak metszeteken 15151800 [Hungarian castles, towns and villages in engravings], Budapest, 2006, 100; JOHANN CHRISTOPH WAGNER, Delineatio Provinciarum Pannoniae, Et Imperii Turcici in Oriente (...), Augsburg, 1684, 18-19.

33

WINFRIED GOLD, Das Zeitalter Max Emanuels und die Türkenkriege in Europa 1683-1687, München, 1976; Kurfürst Max Emanuel - Bayern und Europa um 1700, Band I., Zur Geschichte und Kunstgeschichte der Max Emanuel Zeit, exhibition catalogue, (ed.) Hubert Glaser, München, 1976; JOHANNES ARNDT, Hersschaftkontrolle durch Öffentlichkeit. Die publizistische Darstellung politischer Konflikte im Heiligen Römischen Reich 1648-1750, Göttingen, 2013, 339-392.

34 GERTRUD STETTER, Michael Wening. Leben und Werk des Kupferstecher und Topographia, München, 1964.

35

GYÖRGY RÓZSA, Budapest régi látképei. Alte Ansichten von Budapest 1493-1800, Budapest, 1999, 64-65.

36 GYÖRGY RÓZSA (note 35), 122-123.

37 GYÖRGY RÓZSA (note 35), 128-129, 105 (no. 63).

38 GYÖRGY RÓZSA (note 35) 170-171, 175 (no. 64).

39

GYÖRGY RÓZSA (note 35), 65, 176; JOHN ROGER PAAS, The German Political Broadsheet 1600-1700, vol. 11 (1683-1685), Wiesbaden, 2012, 184, P-3441; GYÖRGY RÓZSA (note 35), 15, 20, 169.

40

GYÖRGY RÓZSA (note, 35), 15, 20, 169, 152, 177-179.

41

GYÖRGY RÓZSA, Schlachtenbilder aus der Zeit der Befreiungsfeldzüge, Budapest, 1987, 21-22.

42

BÉLA OTTÓ KELÉNYI, Buda és Pest grafikus ábrázolásai a visszafoglalás korában 1683-1718, Fővárosi Szabó Ervin Könyvtár Évkönyve, Budapest, 1937; ÁRPÁD KÁROLYI - IMRE WELLMANN, Buda és Pest visszavívása 1686-ban [The reconquest of Buda and Pest in 1686], Budapest, 1936, 117; KARL G. VOCELKA - MARTIN C. MANDLMAYR, "Christliche Triumphfreude über herrliche Victorien und stattliche Kriegsprogressen”. Die Eroberung Ofens 1686. Fallstudie über Zahl, Verbreitung und Inhalte propagandistischer Medien in der frühen Neuzeit, in: Südost-Forschungen, 44 (1985), 99-138.

43 G 1 1703/1 f. 449, "Prospect der Statt Ofen wie solche von StuelWeissenburg zusehen, Prospect der Statt Ofen wie solche von Pest zusehen". 44

G 1 1703/1, f. 449, "Höchst-erfreuliche Relation, was massen die belagerte Vestung Ofen Gegenwart dess vermeinten Türckischen Entsazes ernstlich bestürmet den 2 September dises 1686. Jahrs glücklich erobert (...) Augspurg, bey Jacob Koppmayer”. JOHN ROGER PAAS, The German Political Broadsheet 1600-1700, vol. 12 (1686-1700), Wiesbaden, 2014, 64, P-3537.

45

G 1 1703/1, f. 451. "Eigentlicher Abriss der durch die Christliche Waffen denen Türcken abgenommenen zwey Städte Segedin und Fünffkirchen (...) Nürnberg (...) 1686”; JOHN ROGER PAAS (note 44), 85, P-3561.

46

G 1 1703/1 f. 434. 1682.11. 20/30. "Wahre und eigentliche Abbildung eines Cometen oder Wunder-Sterns"; JOHN ROGER PAAS (note 39), 353, P-3265.

47 G 1 1703/1 f. 453. "Ausführliche Relation und eigentliche Präsentation des (...) Sieges, welchen die Kaiserl. und Chur-Bayeris. Armee den 12. Augusti (...) 1687ten Jahrs auf einer grossen Heyde bey Mohatsch (...)"; JOHN ROGER PAAS (note 44), 122, P-3600. 
48

GERTIE DENEKE - JOHANN HOFFMANN, Ein Beitrag zur Geschichte des Buch- und Kunsthandels in Nürnberg, in: Archiv für Geschichte des Buchwesens, 1 (1958), 337-364.

49

WERNER KAYSER, Thomas von Wiering und Erben. Ein bedeutendes Kapitel hamburgischer Druckgeschichte, in: Auskunft. Mitteilungsblatt Hamburger Bibliotheken, 10 (1990), 343-371.

50

ELMAR SCHMITT, Die Drucke der Wagnerischen Buchdruckrei in Ulm 1677-1804, vols. 1-2, Konstanz, 1984.

51

ORSOLYA LÉNÁRT, Der Ungarische Kriegs-Roman, Medien, Wissen und Fremdwahrnehmung bei Eberhard Werner Happel, Wien, 2016; GERHILD SCHOLZ WILLIAMS, Mediating Culture in the Seventeenth-Century German Novel: Eberhard Werner Happel, 1647-1690, Michigan, 2013, 23-24.

52

G 1 1703/1, f. 495, (1694) in den Augusto haben die Angellande die berühmte französische Seehören in Normandia Dippe und Haure Grace durch einen neuerfundene Machine infernal über eine hauffen geworffen. f. 496. Warhafftiger Abriss der künstlichen Maschine (...) deren sich die Englisch- und Hollandische Flotte, Frankreich zu empfindlichen Schaden, (...) See-Haven und Stadt-Dieppe; JOHN ROGER PAAS (note 44), 235, P-3719.

53

G 1 1703/1, f. 493, Ausführliche Erzehlung der überaus Blutigen Schlacht, welche zwischen Ihro Königl. M. von Engeland und Ihr. Churf. D. in Bayern, wider den Franzözischen Gen. von Luxemburg (...) Tirlemont den 19/29 Julii 1693 gehalten worden; JOHN ROGER PAAS (note 44), 233, P-3717.

54

Relationis Historicae Semestralis Autumnalis Continuatio. Jacobi Franci Historische Beschreibung der denckwürdigsten Geschichten (...), 16 -17, 22-23; BÉLA SZALAI (note 32), 120, 124.

55

Diarium, Oder Kurze Beschreibung, Was täglich bey Belägerung der Vestung Neuhäusel, vom 7. Julii an jezt-lauffenden 1685. Jahrs, (...) Erstlich gedruckt zu Wien, bey Leopold Voigt.

\section{6}

Diarium (note 55), 25-27; ZOLTÁN PÉTER BAGI, A sváb kerületi segélycsapatok kiállításának nehézségei és részvételük az 1685. évi hadjáratban [The Swabian District's Auxiliary Troops in the Campaign of 1685 the Difficulties of their Activation and the Operations], in: Hadtörténelmi Közlemények, 129/1 (2016), 193-210, 204.

57

ZOLTÁN PÉTER BAGI (note 56) 193-210.

58

G 1 1703/1, f. 445, Belagerung Vestung Neuhaeusel Anno 1685. 59

G 1 1703/1, f. 443, Neu-Heusel Hungarisch Vywar (...); ZOLTÁN PÉTER BAGI (note 56), 198-201.

60

G 1 1703/1, f. 447, Abbildung des Türckische Haupt Fahnens so von dess Hochl. Schwaebischen Reichs Craisses Auxiliar Völckern auss der Vestung des Neuhausel zurück gebracht worden.

61

G 1 1703/1, f. 445, "Hoc anno et tempore (1685 18/28 Novembris) haben Ihre Hochstette dehro Heer Margraffen von Durlach dass
Schwäbische Craiss Gen. denen Creiss Collegio dem Türckisch grossen Hauptfahnen von Neuhausel, so von grüner seid mit M...(Text outof-focus) und in dessen Mitte in einen rothen feld mit güldene arabisch Buchstaben gemelte Neun elen lang und Elff elen brait prasentiret."

62

Abbildung und Beschreibung dess Türckischen Haupt-Fähnens welcher von denen dess Hochlöbl. Schwäbischen Reichs-Creisses Auxiliar Völckern in der jüngsthin eroberten Vestung, Neuhäussel gebeutet und zuruck gebracht worden. (...) Matthias Friedrichen Becken E. A. Augsburg, J. Koppmayer. Ottoman military flag with view of Neuhäusel.

63

ALASTAIR HAMILTON, A Lutheran Translator for the Quran. A Late Seventeenth-Century Quest, in: The Republic of Letters and the Levant, (eds.) Alastair Hamilton, Maurits H. van dem Boogart, Bart Westerweel, Leiden, Bonn, 2005, 199-205.

64

ERNST PETRASCH, Die Karlsruher Türkenbeute, in: Badisches Landesmuseum Karlsruhe. Die Karlsruher Türkenbeute. Die Türkische Kammer des Markgrafen Ludwig Wilhelm von Baden-Baden, (eds.) Ernst Petrasch, Reinhard Sänger, Eva Zimmermann, Hans Georg Majer, München, 1991,11-51, 43; GÉZA GALAVICS, Kössünk kardot az pogány ellen. Török háborúk és képzömüvészet [Let us gird our swords against the heathen. Turkish war and art], Budapest, 1986, 114-115.

65

WINFRIED DOTZAUER, Die deutschen Reichskreise (13861806), Stuttgart, 1998, 42, 73; PETER-CHRISTOPH STORM, Der Schwäbische Kreis als Feldherr. Untersuchungen zur Wehrverfassung des Schwäbischen Reichskreises in der Zeit von 1648 bis 1732, Berlin, 1974; ANNEMARIE RÖDER, Die Türkenkrieg und Auswenderung. Historische Erinerungsorte im Südwestdeutschland, in: "Die Schiff" stehn schon bereit. Ulm und die Auswenderung nach Ungarn im 18. Jahrhundert (Forschungen zur Geschichte der Stadt Ulm. Reihe Dokumentation, Band 13), (ed.) Márta Fata, Ulm, 2009., 119-130.

66

HANS EUGEN SPECKER, Die Reichsstadt Ulm als Tagungsort des Schwäbischen Reichskreises, in: Reichskreis und Territorium. Die Herrschaft und der Herrschaft? Supraterritoriale Tendenzen in Politik, Kultur, Wirtschaft und Gesellschaft. Ein Vergleich süddeutschen Reichskreise, (ed.) Wolfgang Wütz, Stuttgart, 2000, 170-196.

67

MAX PLASSMANN, Die Armeen des Fränkischen und des Schwäbischen Reichskreises, in: Zwischen Sonne und Halbmond. Der Türkenlouis als Barockfürst und Feldherr. Begleitband zur Sonderausstellung, (eds.) Daniel Hohrath, Christoph Rehm, Rastatt, 2005, 56-65.

68

G 1 1703/1,f. 478. 1690 Sonntags ad 26 Jan S. V. ist zu Ulm wegen dess Neugekrönte Römischen Königs Joseph I ein kommen und Danckfest gehalten worden.

69

DANIEL SPEER, Ungarischer Oder Dacianischer Simplicissimus (...) Sambt Deß Grafen Tekely Herkommen und biß aufjetzige Zeit verloffenen Lebens-Lauff, 1683.

70

HANS-JÖRG KÜNAST, Die Graphiksammlung des Augsburger Stadtschreibers Konrad Peutinger, in: Augsburg, die Bildfabrik Europas, (ed.) John Roger Paas, Augsburg, 2001, 11-20; HELGA 
MEISE, Medienkonsum oder Wissensdispositif. Zur Stellung von Flugblättern und Flugschriften in Marcus Lamms Thesaurus picturarum (1564-1606), in: Daphnis, 37/1-2 (2008), 153-177.

71

BENEDIKT MAUER, Sammeln und Lesen - Drucken und Schreiben. Die vier Welten des Augsburger Ratsdiener Paul Hector Mair, in: Medien und Weltbilder im Wandel der Frühen Neuzeit (Documenta Augustana, 5), (eds.) Franz Mauelshagen, Benedikt Mauer, Augsburg, 2000, 107-132.

72

GEORG KÖLDERER, "Beschreibunng vnnd Kurtze Vertzaichnus Fürnemer Lob vnnd gedenckhwürdiger Historien” - Eine Chronik der Stadt Augsburg der Jahre 1576 bis 1607, vol. 1-4, (eds.) Silvia Strodel, Wolfgang E. J. Weber (Documenta Augustana, 26), Augsburg, 2013.
73

BENEDIKT MAUER, "Gemain Geschrey" und "Teglich reden". Georg Kölderer - ein Augsburger Chronist des konfessionellen Zeitalters, Augsburg, 2001, 36; SILVIA SERENA TSCHOPP, Wie aus Nachrichten Geschichte wird. Die Bedeutung publizistischer Quellen für die Augsburger Chronik des Georg Kölderer, in: Daphnis, 37 (2008), 33-78.

74

VLADIMIR MAGIĆ, The Janez Vajkard Valvasor Library, in: Blue Blood, Black Ink. Book Collections of Aristocratic Families from 1500 to 1700: International Traveling Exhibition; Zagreb, Martin, Bratislava, Budapest, Burg Forchtenstein, (ed.) István Monok, Budapest, 2005, 41-59; MILAN PELC, Theatrum humanum: Illustrierte Flugblätter und Druckgraphik des 17. Jahrhunderts als Spiegel der Zeit (Beispiele aus dem Bestand der Sammlung Valvasor des Zagraber Erzbistums), Ostfildern, 2013, 139, 134.

Sažetak

Nóra G. Etényi

\section{Grafički plakati u rukopisnoj kronici iz Ulma: Vizualna reprezentacija Ugarskog Kraljevstva na njemačkim političkim letcima tijekom Velikog turskog rata (1683.-1699.)}

Vijesti o ratu protiv Osmanskog carstva bile su popraćene propagandnim materijalima. Izdavačke kuće u Beču, Nürnbergu, Hamburgu i Augsburgu objavljivale su kronike, relevantne vedute, ratne dnevnike, inženjerske planove $\mathrm{i}$ službena izvješća.

O najvažnijim događajima i aktivnostima tijekom Velikog turskog rata svjedočio je i Eberhard Gockel (Göckel, 1636.-1703.), liječnik iz Ulma, u svojem dnevniku pisanom od 1678. do 1703. godine. Prikupljene vijesti o vojnim događanjima sagledao je iz aspekta udaljena svjedoka, istaknuvši najznačajnije trenutke rekonkviste. Kronici je priložio plakate i grafike s prikazima oslobođenih mađarskih utvrda i dvoraca, kao i velikih pobjeda nad Osmanlijama. S dobrim osjećajem za kvalitetu grafika, Gockel je birao djela renomiranih izdavača kao što su Jakob Koppmayer iz Augsburga, Johann Jonathan Felsecker i Johann Hoffmann iz Nürnberga te Michael Wening iz Münchena. Gockelova uporaba bakropisa ukazuje na sličnosti s poznatim suvremenikom i istinskim polihistorom Johannom Weichardom Valvasorom (1641.-1693.). Premda je kranjski aristokrat, sakupivši 7.921 grafiku imao daleko veći potencijal od liječnika iz Ulma, Goeckel se usredotočio na tematski specifične letke nastale 1683.-1687. godine, kupujući ih od Jacoba Koppmayera, Johanna Jonathana Felseckera i Johanna Hoffmana.

Gockel je shvatio političku ulogu protuturske propagande, ali i konkurenciju među saveznicima kada je riječ o reprezentaciji putem tiskanih medija. Kao građanin Ulma poštivao je interes Habsburške kuće, no uglavnom je bio usredotočen na ulogu carskih i švapskih trupa, a pojedina mjesta u tekstu smišljeno je koristio za prezentaciju svojega grada. Njegov ilustrirani rukopis pruža i detaljan opis borbe Ugarskog
Kraljevstva protiv Osmanlija. Uključivši tri različita prikaza opsade tvrđave Nové Zámky 1685. godine, Gockel je pokazao da razumije strateški značaj ponovnog zauzimanja bivšeg središta Kapetanije. Međutim, liječnika nisu zanimale vojne akcije ni pripreme za ponovno osvajanje Budima, o čemu su cjelovite vojne dnevnike objavili Leopold Voigt u Beču i August Hanckwit u Regensburgu. U skladu s Gockelovim konceptom, tiskani dnevnici opisuju borbu tisuću i šesto švapskih vojnika u posljednjem velikom napadu 19 . kolovoza, osobito ističući snažnu jedinicu od tri stotine ljudi u desnoj koloni, koja se uspjela domoći zelene zastave Osmanske garde. Gockel je zabilježio značajnu ulogu švapskih trupa uključivši u svoj dnevnik tri grafička prikaza, među kojima je upravo onaj s osmanskom zastavom koja zaprema dvije trećine kadra, popraćen zapisom da je švapske trupe predvodio grof Charles Gustav od Baden-Durlacha. Ta grafika, rađena prema crtežu Sixtusa Kummera iz Ulma, djelo je poznatog slikara iz Augsburga Johanna Ulricha Kraussa.

Usredotočen na vijesti o ratu s Osmanlijama 1683.-1688. godine, Gockel je zabilježio pobjede nad njima čak i nakon francuske invazije zapadno od rijeke Rajne 1688. godine. Kao kroničar Gockel je bio kritičan prema raznoraznim vojnim vijestima, a pokušao je također ostati nepristran u političkim i vjerskim pitanjima. Gockelova je kronika pružila čitateljima plakata mogućnost kritičkog razmatranja spomenutih događaja, dokazujući da su senzibilitet i znatiželja bili značajan dio identiteta građana Ulma.

Ključne riječi: Eberhard Gockel (1636.-1703.), rukopisna kronika iz Ulma, Veliki turski rat (1683.-1699.), rukopis ilustriran bakropisima, ilustrirani plakati, letci 


\section{Izvori ilustracija i autori fotografija / Sources of illustrations and photo Credits}

\begin{abstract}
Višnja Bralić
The Cult of Saint Euphemia, the Patron Saint of Rovinj, and the Venetian Politics of Co-creating Local Identities in Istrian Communities in the $15^{\text {th }}$ Century / Kult sv. Eufemije, zaštitnice Rovinja $i$ venecijanska politika sukreiranja lokalnih identiteta u istarskim zajednicama 15. stoljeća
\end{abstract}

1: (c) Museo Correr, Venezia (Giuseppe Rosaccio, Viaggio da Venezia a Costantinopoli, per mare e per Terra, \& insieme quello di Terra Santa, Venetia: Giacomo Franco, 1598, fol. 7v)

2-10: Ljubo Gamulin

\section{Anna Boreczky}

Historiography and Propaganda in the Royal Court of King Matthias: Hungarian Book Culture at the End of the Middle Ages and Beyond / Historiografija i propaganda na dvoru kralja Matije Korvina. Mađarska kultura knjige krajem srednjega vijeka i dalje

1-11, 14, 16-18: @ National Széchényi Library, Budapest (Országos Széchényi Könyvtár)

12, 13: ( ) Heidelberg University Library (Universitätsbibliothek Heidelberg)

15: From Wikimedia Commons, the free media repository

\section{Ivan Gerát}

Saint George Between Media and Functions / Sv. Juraj izmedu medija i funkija

1: Image courtesy National Gallery of Art, Washington DC

2: https://www.metmuseum.org/art/collection/, Public Domain

3: https://www.metmuseum.org/art/collection/, Public Domain

4, 5: Ivan Gerát

6: Archive of the Institute of Art History of the Slovak Academy of Sciences

\section{Ivan Ferenčak}

The Illustrations in the Glagolitic Books Printed by Bishop Šimun Kožičić Benja in Rijeka (1530-1531) / Ilustracije u glagoljskim knjigama biskupa Šimuna Kožičića Benje tiskanim u Rijeci (1530.-1531.)

1: Tamara Runjak, Rijetkosti u Knjižnici Hrvatske akademije znanosti i umjetnosti: katalog inkunabula i knjiga 16. stoljeća, Zagreb, 2011.

2, 7-10: Zagreb, Knjižnica Hrvatske akademije znanosti i umjetnosti, R-600, snimio Ivan Ferenčak 2019.

3: Ivan Ferenčak, 2019.

4: Biblioteca nazionale Marciana, Venezia, BM - Rari Ven. 579 (su concessione del Ministero per i Beni e le Attività Culturali - Biblioteca Nazionale Marciana. Divieto di riproduzione).

5: Biblioteca nazionale centrale di Firenze, Firenze, MAGL.2.1.109 (su concessione del Ministero dei beni e delle attività culturali. Biblioteca Nazionale Centrale di Firenze. Divieto di riproduzione)
6: Bibliothèque nationale de France, Paris, département Musique, RES-1527.

11: Nacionalna i sveučilišna knjižnica, Zagreb, RIIA- $8^{\circ}-8$.

12: Nacionalna i sveučilišna knjižnica, Zagreb, RIIA-16º-5.

\section{Milan Pelc}

Panegyric Emblem Books, Jesuits and the Habsburg Emperors: Some Examples Related to $17^{\text {th }}$-Century Croatia / Panegirički amblemi $i$ habsburški carevi - primjeri iz 17. stoljeća povezani s hrvatskom kulturnom sredinom

1: ๔ Hrvatski povijesni muzej, Zagreb / Croatian History Museum 2: ( University Library, Budapest / Egyetemi Könyvtár, Kézirattár 3-20: ๑ Austrian National Library, Vienna / Österreichische Nationalbibliothek

\section{Polona Vidmar}

Coesari in mis omni hora fidelis servivi: The Portraits of Sigismund Herberstein and Walter Leslie in Diplomatic Robes / Cæsari in mis omni hora fidelis servivi: Portreti Žigmunda Herbersteina $i$ Waltera Leslieja u diplomatskim odorama

1-2, 4, 6: Knjižnica Ivana Potrča Ptuj / Ivan Potrč Library Ptuj 3: Hollstein's German Engravings, Etchings and Woodcuts 1400-1700, vol. XIII A, 1984

5, 10, 13: Google Books

7-9, 11-12: Polona Vidmar

\section{Nóra G. Etényi}

Broadsheets with Engravings in a Manuscript Chronicle from Ulm: Visual Representations of the Hungarian Kingdom on German Political Leaflets during the War of Reconquest (1683-1699) / Grafički plakati u rukopisnoj kronici iz Ulma: Vizualna reprezentacija Ugarskog Kraljevstva na njemačkim političkim letcima tijekom Velikog turskog rata (1683.-1699.)

1, 4: (C) Austrian National Library Portrait Collection, Vienna / Österreichische Nationalbibliothek Porträtsammlung

2, 3, 6: @ Hungarian National Museum, Budapest / Magyar Nemzeti Múzeum

5, 7: @ National Széchényi Library, Budapest, Apponyi Sammlung / Országos Széchényi Könyvtár, Apponyi Metszet

\section{Werner Telesko}

Graphic prints of the Josephine period (1765/1790) and the propaganda of 'Religious Tolerance' / Grafički listovi Jozefinskog razdoblja (1765./1790.) i propaganda "Vjerske tolerancije"

1: ( ) Austrian National Library, Vienna

2: () Austrian National Library, Vienna

3: ㄷ Vienna Museum 
4: (C) Vienna Museum

5: (C) Vienna Museum

6: C Vienna Museum

\section{Martina Frank}

Representing the Republic in Seventeenth-Century Venice / Predstavljanje Republike u Veneciji 17. stoljeća

1, 3, 4, 5, 12: @ Austrian National Library, Vienna / Österreichische Nationalbibliothek

2, 15: Martina Frank

6: () University Library of Padua / Biblioteca universitaria di Padova

7: @ McNay Art Museum

8: Cat Bauer (https://venetiancat.blogspot.com/2016/11/thanksgiving-in-venice-celebrates-black.html)

9, 10: https://www.lamoneta.it/topic/157941-medaglia-nicol\% C3\%B2-contarini/

11: ๑ José Luiz Bernardes Ribeiro / CC BY-SA 4.0

13: Internet culturale

14: () Marciana National Library / Biblioteca Nazionale Marciana, Venezia

16: ( ) Museo Civico del Castello di San Giusto, Trieste

\section{Bálint Ugry - Maja Žvorc}

The Čakovec Stone Bust Collection: New Identifications, Possible Dating and the Identity of its Commissioner / Zbirka kamenih bisti u Čakovcu: Nove identifikacije, moguće datacije i naručitelj

1, 4, 6, 8, 10: Jovan Kliska

2: ๑ Austrian National Library (Österreichische Nationalbibliothek), Vienna

13, 15: ( ) Museum of Međimurje (Muzej Međimurja), Čakovec

3, 5, 7, 9, 11, 14, 16: Corpus Juris Hungarici, Tyrnaviae, 1751.

12: ( National Széchényi Library (Országos Széchényi Könyvtár), Budapest

17, 18: @ National Archives of Hungary (Magyar Nemzeti Levéltár), Budapest

19: Bálint Ugry

\section{Damir Tulić}

Glory Crowned in Marble: Self-promotion of Individuals and Families in Seventeenth- and Eighteenth-Century Monuments in Istria and Dalmatia / Slava okrunjena mramorom: Samopromocija osoba $i$ obitelji na spomenicima 17. i 18. stoljeća u Istri i Dalmaciji

1, 2, 3, 4, 5, 6, 7, 8, 9, 10, 11, 12, 13, 15, 16, 17: Damir Tulić

14: Samo Štefanac

\section{Jasminka Najcer Sabljak}

Portraits of Habsburg Rulers in the Aristocratic Collections of Eastern Croatia / Portreti vladara obitelji Habsburg u plemićkim zbirkama istočne Hrvatske

\author{
1, 2: ( $)$ Galerija Matice srpske, Novi Sad \\ 3: Francisca Clary-Aldringen \\ 4: Davor Šarić
}

\section{Danko Zelić}

Projekt Fausta Vrančića za opsadu Ostendea iz 1603. godine / Faust Vrančićs Design for the Siege of Ostend from the Year 1603

1: Matthias Dögen, Architectura militaris moderna (...), Amstelodami, 1647., 354-355.
2-4: ( ) Rijksarchief in België / Archives de l'État en Belgique, Algemeen Rijksarchief / Archives générales du Royaume, Fond Duitse Staatssecretarie / Secrétairerie d'État Allemande, 413, p. 309

5: Pompeo Giustiniano, Delle guerre di Fiandra libri 6. Di Pompeo Giustiniano del Consiglio di guerra di S. M. C. (...) Posti in luce da Gioseppe Gamurini (...) con le figure delle cose più notabili, In Anversa, 1609., 84-85

\section{Radoslav Tomić}

Generalni providur Leonardo Foscolo i umjetnost u Dalmaciji / Provveditore generale Leonardo Foscolo and Art in Dalmatia

1-30: Fotografije iz arhive autora

4: Presnimak iz: Alfons Pavich pl. Pfauenthal, Prinosi povijesti Poljica, Sarajevo, 1903., 79.

\section{Petar Puhmajer}

Dvorac Cernik - kontinuitet i mijene predturskog nasljeđa u barokno doba / The Cernik Castle - Continuity and Change in the Pre-Ottoman Heritage during the Baroque Era

1, 2, 9: Paolo Mofardin, Fototeka IPU

3 a, b; 6 a , b c c, d: arhitektonski snimak Sanja Štok i Barbara Kulmer, grafička obrada Marin Čalušić

4, 7, 10, 11: Petar Puhmajer

5: ๑ Generallandesarchiv, Karlsruhe

\section{Bojan Goja}

Kuća Cattinelli 1772. godine: prilog poznavanju stambene arhitekture u Zadru u 18. stoljeću /

The Cattinelli House in 1772: A Contribution to Our Knowledge of Housing Architecture in $18^{\text {th }}$-Century Zadar

1, 2: Bojan Goja

3, 4: Branko Maroević, dipl. ing. arh., izrada nacrta

\section{Iva Pasini Tržec}

Slike starih majstora iz zbirke Ervina i Branke Weiss u Strossmayerovoj galeriji u Zagrebu / Paintings of Old Masters from the Collection of Ervin and Branka Weiss in the Strossmayer Gallery in Zagreb

1, 3, 6: Arhiv Strossmayerove galerije HAZU, dokumentacija Weiss 2: MAK - Museum of Applied Arts (Museum für angewandte Kunst), Vienna

4: RKD - Netherlands Institute for Art History (Rijksbureau voor Kunsthistorische Documentatie), Den Haag

5: Palais Liechtenstein, Vienna

6: ( ) Strossmayerova galerija starih majstora HAZU

7: BDA - Bundesdenkmalamt Archiv (Federal Monuments Authority Austria Archive), Vienna

\section{Irena Kraševac}

Prva tri djela u fundusu Moderne galerije Društva umjetnosti / The First Three Artworks in the Holdings of the Modern Gallery of the Art Society in Zagreb

1, 4: Goran Vranić, Moderna galerija, Zagreb

2: Paolo Mofardin, Institut za povijest umjetnosti, Zagreb

3: digitalna presnimka iz kataloga izložbe: Ivan Meštrović. Skulpturen, Nationalgalerie, Staatliche Museen Preußischer Kulturbesitz, Berlin, 1987. (Nenad Gattin?)

5: Arhiv Galerije grada Praga / Archive of Prague City Gallery 